\title{
La Barranca del Rio Santiago as Tourist and Eco Touristic Attraction for the Brand Guadalajara Guadalajara, Focused on a National Tourism
}

\author{
José G Vargas-Hernández, University Center for Economic and Managerial Sciences, University of Guadalajara, \\ Guadalajara, Mexico \\ Jovanna Nathalie Cervantes-Guzman, University Center for Economic and Managerial Sciences, University of \\ Guadalajara, Guadalajara, Mexico
}

\begin{abstract}
The main purpose of this research is to show if the Barranca del Rio Santiago is a tourist attraction and ecotourism should be included in the Guadalajara brand, focused on national tourism. The research is exploratory and descriptive in nature, as it seeks to know if the Rio de Santiago Canyon is an ecotourism and tourist attraction so that it can be included in the Guadalajara brand. The analysis was conducted under a database issued by the state of Jalisco, which is the 2016 Yearbook of the State of Jalisco. SECTUR establishes in the latest competitiveness agenda of tourist destinations in Mexico that Guadalajara has a large number of natural destinations, including the Barranca del Río Santiago, this destination has a high ecological, recreational and landscaping value, which is very little known by the local population, and consequently it can become a new product for the ecotourism sector.
\end{abstract}

\section{KEYWORDS}

City Brand, City Marketing, Ecotourism, Guadalajara, Guadalajara

\section{INTRODUCTION}

In the following investigation, it is analyzed if the Barranca del Río Santiago can be a tourist and eco touristic attraction for the city of Guadalajara, focused on a national tourism. That is why it is talked about the terms tourism, alternative tourism, national tourism, ecotourism, which is a tourist attraction, the city or city marketing brand, the Guadalajara brand and the Barranca del Río Santiago. All these terms are based on several expert authors on the subject and official documents which are provided by the Secretary of Tourism of the State of Jalisco.

Undoubtedly, city brands are something that has been raised for a long time and there are success stories, very famous, such as I Love NY or what is the CDMX brand (Aldaz, 2016). Another important aspect of the research is that the Guadalajara brand was launched by the government of Guadalajara in 2016 with the characteristic song of the composer Pepe Guízar (Social communication, events, government news 2016).

Regarding tourism issues, it is commented that tourism is an economic force, which has the power to implement projects that maintain the natural attractiveness that visitors wish to see and experience. The economic benefits of tourism depend on the way in which tourist attractions are 
kept safe, clean and pleasant to the senses (Rebollo, 2012, p.12). Alternative tourism refers to there are other ways of doing things. For example, traveling and knowing places, more natural. (Rogel, Rojas \& Ortega, 2011, p.3).

However, it is necessary to define perfectly what fraction of tourists are going to be taken from national tourism, which is practiced by nationals and foreigners residing in the country within its borders, that is, tourists traveling inland. of the country they do it for vacation reasons, recreation, congresses and conventions, work and business (Portugal, 2008). Then, it can have segmented it more and reach the ecotourism sector, which is considered the direct result of global acceptance in favor of more sustainable productive practices and with less impact on the environment.

\section{THE RESEARCH PROBLEM}

\section{Statement of the Problem}

The city marketing is an event that has generated debates, because on the one hand it is noted that the commercialization of territories has existed for centuries, and on the other hand, it is maintained that it is a trend that arises from the seventies and eighties (Weapons, 2007). However, we have other authors who comment that "The marketing of city (city marketing) can be defined as an active policy of actions aimed, on the one hand, to identify and determine the needs of its different audiences, real and potential; and another part to develop a series of products and services in the city to meet those needs, creating and enhancing their demand (Rojano \& Castilla, 2007).

There are success stories of the brands of cities, for example, I love NY" (Marín, 2010). In Mexico there is currently the brand Visit Mexico (CPTM, 2017), however, Guadalajara wanted to make its own city brand which carries the Guadalajara slogan created in 2016 as an identity element, tool for promotion and positioning of the city de Guadalajara (Social communication, events, government, news, 2016). The creators of the brand were based on the song of Pepe Guízar, since it represents a natural symbol of the city and reinforces emotions and ideas already positioned, with the characteristic choir Guadalajara, Guadalajara. In the same way, the adaptation of the song of the aforementioned composer, in which different styles of music such as mariachi, rock, electronic, jazz and regional music was mixed, also mixed a variety of singers with the intention to integrate all of Mexico (Catellanos, 2015).

An important factor is the intervention of the tourism sector. Troisi defines tourism as the set of temporary transfers of people originated by needs of rest, cure, spiritual or intellectual (Betancourt, 2008). An important factor is to take into account the national tourism which is defined as the tourists that move in the interior of the country do it for vacation reasons, recreation, congresses and conventions, work and / or business, etc. (Portugal, 2008).

It is also important to point out that, according to Ipsos, the advertising tracking of the preliminary tourism promotion council, taking into account 3 indicators which mention that in $2017,46 \%$ of people visit a place are by advertising attribution; $90 \%$ are people who intend to travel and the third indicator by brand awareness which nationally does not have any percentage. Similarly, a national survey on Pride of the Mexican in 2016 conducted by the consultancy Mitofsky mentions that $9.9 \%$ of the 1,000 respondents over 18 years old answered that Guadalajara was the first city where Mexicans felt most proud (Mitofsky Consultant, 2016).

According to experts who elaborated the competitive agenda of tourist destinations in Mexico, they pointed out that Mexico has not been able to take advantage of the total benefits offered by tourism, a clear example of this is the city of Guadalajara, which is one of the most emblematic states in Mexico. This city is highlighted by its great cultural contribution, tradition and historic buildings, however, it has not been able to take advantage of the natural heritage it has to give it recreational or tourist use, since it has great potential in this sector as it is the Canyon of the Santiago River (SECTUR, 2014). 
After all these data provided a gap is created which becomes the purpose of the research that consists of knowing how attractive ecotourism can be so that it can be added to the Guadalajara brand and what the potential areas may be. With the intention of contributing this study to the corresponding authorities in the tourism sector and for the expansion of the labor market in a way that will enable them to carry out ecotourism activities. Taking into account that the definition of tourist attraction, the dictionary of tourist terminology of the Argentine National Tourism Direction mentions that a tourist attraction is the natural, cultural, sports or any other type that can generate enough interest to attract tourists (Navarro, 2015).

\section{Justification}

In this research, it is asked if the Barranca del Río Santiago is a tourist and eco touristic attraction for the Guadalajara city brand, in order to be able to promote recreational and tourist use of the areas of the city of Guadalajara that are not well known, considering that it may have a greater attraction for national tourism, since the proximity of these areas can be very attractive for people who live in the city of Guadalajara and have the taste to enjoy natural environments near them. It is also intended that it can serve as support the development of new programs either for the Secretary of Tourism (SECTUR).

\section{Research Objectives}

\section{General Objectives}

Determine the feasibility of the Santiago river canyon being a tourist and ecotourism attraction for the Guadalajara, Guadalajara brand, for national tourism.

\section{Specific Objectives}

1. Expose places of tourist attraction of Guadalajara, for recreational uses.

2. Present the profile of the ecotourism.

3. Expose the training of qualified personnel to attend the national Eco tourists

\section{Hypothesis}

\section{General Hypothesis}

Is it possible that the Santiago river canyon is a tourist attraction and ecotourism for the Guadalajara brand, with a focus on national tourism?

\section{Specific Hypothesis}

1. Expose that the Barranca del Rio Santiago is a tourist and ecotourism attraction in Guadalajara.

2. Is the ecotourism sector profitable for national tourism?

3. Are there enough trained personnel for the ecotourism sector?

\section{LITERATURE REVIEW}

As it can see in the literature review, although there are several investigations that expose it to ecotourism, tourist attractions, city marketing and the ravine of the Rio de Santiago, so far there is no research that integrates the above, being the void of literature. Therefore, the research focused on integrating the variables to show if the Barranca del Rio Santiago is a tourist attraction and ecotourism is attractive to be included in the Guadalajara brand, focused on national tourism. 


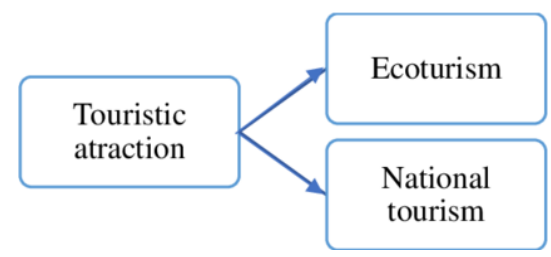

\section{CONTEXTUAL FRAMEWORK}

\section{Tourism}

Tourism is the sum of the phenomena and relationships that arise from the journey and the permanence of non-residents, as long as they do not establish a permanent residence and do not relate to any remunerated activity. This definition was entrusted to Professors Hunziker and Krapf, likewise Troisi defines it as the set of temporary transfers of people originated by needs of rest, cure, spiritual or intellectual (Betancourt, 2008). Later authors like Burkart and Medlik define that they are the short and temporary displacements of people towards destinations outside the place of residence and work, and the activities undertaken during the stay in those destinations (Sancho, 2008).

Mathieson and Wall mention that tourism is the temporary movement of people, for periods of less than one year, to destinations outside the place of residence and work, the activities undertaken during the stay and the facilities created to meet the needs of the tourists (Sancho, 2008). Professor Arriaga mentions it as tourism is all temporary displacement determined by causes beyond profit: The set of goods, services and organization that in each nation determine and make possible those trips, and the relationships and events between them and travelers take place (Betancourt, 2008). However, after so many definitions, the World Tourism Organization (UNWTO) in 1994 is defined as tourism includes the activities carried out by people during their trips and stays in places other than their usual environment, for a period of time consecutive less than a year for leisure, business and other purposes (Sancho, 2008).

In this research the UNWTO definition it is used because it is the main international organization in the tourism field with 158 countries, 6 associate members and more than 500 private members (UNWTO, 2018). Authors such as Óscar de la Torre Padilla, defines it as tourism is a social phenomenon that consists in the voluntary and temporary displacement of individuals or groups of people who, mainly for recreation, rest, culture or health, move from their place from habitual residence to another, in which they do not exercise any gainful or remunerative activity, generating multiple interrelations of social, economic and cultural importance (Betancourt, 2008).

Tourism is an economic force, which has the power to implement projects that maintain the natural appeal that visitors want to see and experience. The economic benefits of tourism depend on the way in which tourist attractions are kept safe, clean and pleasant to the senses (Rebollo, 2012). As important is the tourist development has brought strong impacts on the environment such as river pollution, acoustics, aesthetics. Although the most important impacts include the loss of biological diversity and the limitation of natural resources on which tourism activity is based.

This overexploitation of resources has increased in recent years to unsustainable levels. Tourism cannot work without the basic natural resources on which it is based since its own environmental degradation directly affects its supply and can endanger the tourist activity itself. For all these reasons, various organizations and conventions in recent years have become aware of the importance of conserving the natural environment to apply not only to the tourism sector but to all social areas to achieve sustainable development (Betancourt, 2008). As tourism develops, it must make the preservation of the environment a priority. The tourism industry will have to protect and preserve natural tourist attractions, the environment, fragile ecosystems and living cultures of remote regions. In this way tourists will continue to travel (Rebollo, 2012). 


\section{Alternative Tourism}

Alternative tourism is defined by the SEMARNAT as the trips that have the purpose of carrying out recreational activities in direct contact with nature and the cultural expressions that surround it with an attitude and commitment to know, respect, enjoy and participate in the conservation of the natural and cultural resources. Alternative tourism is the product of international policies to conserve the environment and is a response in Mexico to environmental policies that aim to conserve natural resources (Rogel, Rojas \& Ortega, 2011). Like Neyra, he mentions that alternative tourism refers to there are other ways of doing things. For example, traveling and knowing places (alternative tourism), is not exempt from new alternatives, in this concept the most important thing is contact with nature and indigenous cultures, that is to say, soaking up what is specific to the region to visit (Rogel, Rojas \& Ortega, 2011).

\section{National Tourism}

The World Tourism Organization provides the following definition of national tourism: National tourism encompasses domestic tourism and outbound tourism, namely, the activities carried out by resident visitors inside and outside the reference country, as part of their tourist trips. inmates or issuers (UNWTO, 2008). It can also be taken as a definition that national tourism is practiced by nationals and foreigners residing in the country within its borders, that is, tourists who travel within the country do so for holiday reasons, recreation, congresses and conventions, work and/or business, etc. (Portugal, 2008).

\section{Ecotourism}

Ecotourism is according to Diamantis and Ladkin the direct result of global acceptance in favor of productive practices more sustainable and with less impact on the environment. However, another author is Jost Krippendorf who is considered the pioneer in this concept making a strong criticism to the mass tourism under the argument of its destructive potential in the environment and economy within the receiving communities, recognizing the need to look for a new option (Rebollo, 2012).

The function of ecotourism is to protect and care for the environment, with the intention of not manipulating nature but contemplating and admiring its beauty. To know those who have lived forever in these ecosystems, from the ancestral cultures, to their flora, the healing qualities and their fauna to respect the place. Usually ecotourism centers are found in ecologically protected areas (Rebollo, 2012). Similarly, it seeks to break with the idea that what is legitimately tourism is only in large hotel chains, entertainment centers, restaurants and finally that the natural space must be transformed at the convenience of being human (Melo, 2013).

\section{Tourist Attraction}

As one of the first definitions we find Zimmermann, who defines it as the tourist attractions are tourist resources that have the necessary conditions to be visited and enjoyed by tourists, that is, they have tourist facilities, means of transport, services complementary and basic infrastructure. The tourist attractions should be considered as resources because they have generated an economic activity and represent foreign currency in a country's economy (Castellanos, 2015).

For its part, Acerenza identifies the tourist attractions as the most important component of the tourism product because they determine the selection, by the tourist, of the point of destination of their trip, and are the ones that generate, therefore, a current tourism to its location and also points out that they constitute the main reason for the tourist to visit the destination and are able to satisfy the primary motivations of tourists' travel (Navarro, 2015). Finally, the dictionary of tourism, hospitality and transport, offers a definition of tourist attraction, which says that considers that it is an object or event capable of motivating a tourist to leave his home to move to know him (Wallingre \& Toyos, 2010). 


\section{City Brand or City Marketing}

The term City Marketing has been misunderstood on many occasions, reducing it to a mere promotion activity through which to show a city, mainly in the face of tourism, relying on more or less recurrent speeches: brochures with photos of the main monuments, regional costumes, local cuisine and party program. But what is talking about is a much broader and more powerful conception. It is about transferring the focus and marketing tools that are applied to a company or product, to the city, as an essential tool in the development of their strategies and their competitiveness (Romero, 2009).

City marketing is conceived as the city in the marketing as a product, which faces a competitive market formed by thousands of municipalities and where millions of agents converge, also directs its activity towards the citizens of the municipality visitors, tourists and the investors this according to (Betancourt, 2008). However, it is known that the term of City marketing was introduced in European literature in the 80's. The City Marketing for Kotler, Haider and Rein is constituted as a strategy of development of the city oriented to satisfy, better than other competing cities, the needs of the current and future users of all the services of the city (Heredero, 2015).

Other authors mention that globalization and the extension of competition, the value creation of the local: the rapid evolution of communication tools and, finally, the evolution of marketing are factors that undoubtedly determine urban marketing city (Benko, 2000). It can be also found another definition about city marketing and it is defined as City marketing can be defined as an active policy of actions oriented, on the one hand, to identify and determine the needs of its different public, real and potentials; and another part to develop a series of products and services in the city to meet those needs, creating and enhancing their demand (Rojano \& Castilla, 2007).

\section{THEORETICAL FRAMEWORK}

\section{Tourism}

It is said that tourism comes to diversify the economy providing foreign exchange necessary to boost economic development, but also the proponents of the development of tourism argue that tourism not only generates foreign exchange, but also alleviates a little the problem of unemployment and long term can provide a substitute for traditional exports whose fruit is more insecure than tourism (Portugal, 2008). But always have to take into account the tourist demand which make up tourists, travelers and visitors, after this term is a heterogeneous group of people, an aggregate of personalities with different characteristics and interests such as: social, economic, recreational (Portugal, 2008), in these demands is a group called minority tourism which are characterized by traveling individually, family and in groups, their chosen nuclei are little touristy and do it at any time of the year because their economic possibilities allow it (Portugal, 2008).

While it is true that there are many types of demand, this segment prefers that the consumer of this type of service, could give a better idea of the activities and products that must be offered. Not without first clarifying that, for each activity or specialty in particular, there is a market segment with its own characteristics (Rogel, Rojas \& Ortega, 2011), that is, each segment has its profile well specified. Undoubtedly, the demand is important, but it is also important to say that the trips have as a purpose to perform recreational activities of appreciation and knowledge of nature through contact with it. These activities can be observation of stars, observation of flora and fauna, hiking, environmental education, biological research, observation of attractions and special phenomena of nature, and observation of natural attractions among others (Rogel, Rojas \& Ortega, 2011).

As natural resources, Tourism Secretary (SECTUR) in the year of 2005 mentioned that natural or cultural resources are the environment, the archaeological wealth and the historical expressions of tradition, these are considered the base of the tourist product, so that this resource becomes attractive tourist man must incorporate facilities, equipment and services, thus adding value in economic terms (Portugal, 2008). But as to know if a place has tourist attraction or not, in this sense, the CICATUR- 
OEA (Inter-American Center for Tourism Training of the Organization of American States) proposed in 1974 a scale of valuation of tourist resources that quickly spread in Latin America and of practically exclusive use until now, as shown in Table 1 (Navarro, 2015)

Similarly, there are other ways to classify a tourist attraction, since other authors say that it should analyze tangible and intangible resources, which are amenable to tourism and consider the potential for attraction, which may motivate a non-profit movement; in the same way the accessibility of arriving; signage with tourist guides, brochures, urban signs; the level of affluence; the level of use; the elements of valuation; and the current or possible activities related to the local resource (Navarro, 2015).

However, it can also be carried out with the following hierarchical criteria: first those that do not have sufficient merit but that can complement others of higher hierarchy: then those that have some striking feature and motivate those who arrive at the place by others attractive, then those that have exceptional features with the capacity to motivate national demand, either alone or together with other attractions; and finally those that have exceptional features and great significance for the international market capable of motivating the tourist displacement of that demand alone (Wallingre, 2011).

Table 1. Hierarchization of tourist resources

\begin{tabular}{|c|c|}
\hline Hierarchy 5 & $\begin{array}{l}\text { Exceptional attraction of great significance for the international tourist } \\
\text { market, capable on its own of motivating an important current of visitors } \\
\text { (current or potential), quantified as a percentage of the total demand of } \\
\text { the country, or of a specific market. Equivalent to the only resource in the } \\
\text { world. }\end{array}$ \\
\hline Hierarchy 4 & $\begin{array}{l}\text { Attractive with exceptional features in a country, capable of motivating a } \\
\text { current (current or potential) of visitors of the internal or external market, } \\
\text { but in a lower percentage than those of hierarchy 5, either by itself or in } \\
\text { conjunction with other attractions contiguous. Equivalent to a single } \\
\text { resource in the country. }\end{array}$ \\
\hline Hierarchy 3 & $\begin{array}{l}\text { Attractive with some striking feature, able to interest long distance } \\
\text { visitors, whether from the internal or external market, who had come to } \\
\text { your area for other tourism reasons; or to motivate local tourist currents } \\
\text { (current and potential). Equivalent to a single resource in a subnational } \\
\text { jurisdiction. }\end{array}$ \\
\hline Hierarchy 2 & $\begin{array}{l}\text { Attractions with sufficient merits to be considered important for the } \\
\text { domestic market, but without conditions for receptive tourism and that are } \\
\text { part of the tourist heritage». Equivalent to a single resource in a locality. }\end{array}$ \\
\hline Hierarchy 1 & $\begin{array}{l}\text { Attractiveness without sufficient merits to be considered in the previous } \\
\text { hierarchies, but also part of the tourist heritage as elements that can } \\
\text { complete others of higher hierarchy in the development and operation of } \\
\text { any of the units that make up the tourism space. Equivalent to } \\
\text { complementary resource. }\end{array}$ \\
\hline Hierarchy 0 & $\begin{array}{l}\text { Attractions whose qualities do not allow them to be incorporated into } \\
\text { hierarchy } 1 \text {, which is the minimum hierarchical threshold. Equivalent to } \\
\text { a resource without relevant characteristics (it is not a tourist resource). }\end{array}$ \\
\hline \multicolumn{2}{|c|}{ 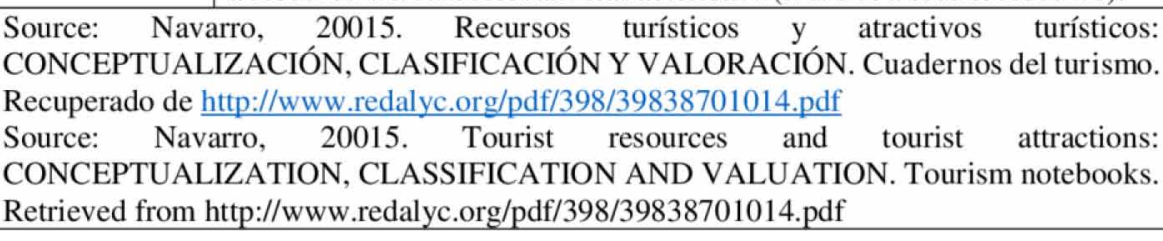 } \\
\hline
\end{tabular}




\section{Ecotourism}

Ecotourism is perhaps the word that has commercially been more successful in the development and marketing of a novel tourism activity, associated with the use of the natural and cultural resources of a region. Due to its commercial success, it has also been lent to an indiscriminate use that has forced the creation of new terminologies that allow the product to be differentiated and to guarantee its quality in some way (Báez \& Acuña, 1998). For Latin America, some events that refer to the general background of the adoption of ecotourism in Latin American countries are presented below (Table 2).

Ecotourism must be developed under the following values and must be followed by both the tourist and the local people:

1. Responsible for the use and management of tourist attractions.

2. Respectful of the communities where the activities are carried out.

3. Honest with the product to preserve its authentic conditions while presenting to the tourist.

4. Educational so that the visitor acquires new knowledge of the visited place.

5. Interactive by allowing direct contact with natural and cultural resources.

6. Democratic so that the benefits obtained are shared equally (Romero, 2008).

Profile of the ECOTOURIST (Báez, 1996)

1. Interested in having direct contact with nature

2. Interested in knowing different ways of understanding and living life (which seeks a cultural exchange)

3. Willing to learn, always active and dynamic

4. Generally educated and with some prior knowledge about the destination, the resource to visit and the possible activities to be carried out

5. Careful of your physical and emotional condition

6. Prefers direct contact with people and seeks to establish friendships (Prefers a personalized service with a quality seal)

7. Is willing to collaborate with initiatives for better waste management, reduction of water and energy consumption and any other effort to reduce the negative impact.

To any ecotourism activity, whether at the national, regional or local level, it is essential to build inventories of ecotourism attractions, both existing and potential, since the national inventory of ecotourism attractions is nothing more than the sum of the different regional ecotourism inventories (Lascuráin, 1998). As part of the inventory of natural resources are lakes, rivers, beaches, mountains, valleys and meadows. They not only allow to extract food and raw materials, but they are also admirable for their great beauty, therefore, these natural resources are also considered as tourist inventory (Rebollo, 2012).

It is possible to identify areas and natural attractions as the most important elements of the tourist system that motivate the visit and that offer tourists experiences and unique memories, because first there are the natural resources and the components of their environment. Lakes, lagoons, mountains, valleys, deserts, jungles, plains, beaches, estuaries, hills, mountains, ravines, snowy mountains and second place is any destination is characterized mainly by its type of ecosystem, i.e. the nature and appearance of its landscape; and its climate, the type of cold conditions of heat, humidity, winds, height and specific characteristics given by its altitude and location in the hemisphere (Rebollo, 2012). The ecotourism attractions of an area can be classified into three basic categories:

1. Focal Attractions: Which from a specific area or region will always refer to the distinctive elements of natural and / or cultural heritage found in that area. They are those intrinsic features of 


\begin{tabular}{|c|c|c|}
\hline Date a & vent & Agreements and achievements \\
\hline $\begin{array}{lr}\text { December } & 1974 \\
\text { San José, } & \text { Costa } \\
\text { Rica } & \end{array}$ & $\begin{array}{l}\text { "First Central } \\
\text { American Meeting } \\
\text { on Management of } \\
\text { Natural and Cultural } \\
\text { Resources" }\end{array}$ & $\begin{array}{l}\text { It was proposed the creation of a system of parks } \\
\text { and reserves in areas of great environmental and } \\
\text { cultural diversity and with high tourism } \\
\text { potential. It was also proposed to set up a } \\
\text { regional committee for the conservation of } \\
\text { resources and adapt legislation for efficient } \\
\text { management (CATIE, 1989). }\end{array}$ \\
\hline $\begin{array}{l}1974 \text { Coyococ, } \\
\text { Mexico }\end{array}$ & $\begin{array}{l}\text { "Seminar on Models } \\
\text { of Utilization of } \\
\text { Natural Resources, } \\
\text { Environment and } \\
\text { Development } \\
\text { Strategies" }\end{array}$ & $\begin{array}{l}\text { In this seminar, alternative models of socio- } \\
\text { economic development were determined that } \\
\text { contemplate the environmental and cultural } \\
\text { characteristics of each region in order to reduce } \\
\text { the inequity generated current modes of } \\
\text { consumption and production (González, 2001). }\end{array}$ \\
\hline $1975 \quad \mathrm{El}$ & $\begin{array}{ll}\text { "IV Meeting of } \\
\text { Ministers } & \text { of } \\
\text { Agriculture } & \text { of } \\
\text { Central America" } & \end{array}$ & $\begin{array}{l}\text { Based on this meeting, the con } \\
\text { restoration and treatment of natural } \\
\text { was established as a priority, as the } \\
\text { welfare and local development (CATI }\end{array}$ \\
\hline $\begin{array}{l}1986 \quad \text { Caracas, } \\
\text { Venezuela }\end{array}$ & $\begin{array}{l}\text { "Workshop on } \\
\text { planning of national } \\
\text { systems of protected } \\
\text { wild areas in Latin } \\
\text { America" }\end{array}$ & $\begin{array}{l}\text { be a system of legally } \\
\text { areas for these areas to b } \\
\text { (Cracco, 2006). }\end{array}$ \\
\hline 1987 & $\begin{array}{l}\text { Second "Central } \\
\text { American Meeting } \\
\text { on Management of } \\
\text { Natural and Cultural } \\
\text { Resources" } \\
\end{array}$ & $\begin{array}{l}\text { The objective was to e } \\
\text { strengthen the system of } \mathrm{p} \\
\text { and promote conservation } \\
\text { (CATIE, 1989). }\end{array}$ \\
\hline 19 & \begin{tabular}{|l|} 
"International \\
Workshop on \\
Interpretation in \\
Wild Protected \\
Areas" \\
\end{tabular} & cted \\
\hline 199 & \begin{tabular}{|lr} 
"International & \\
Workshop & on \\
management & of \\
biosphere reserves"
\end{tabular} & $\begin{array}{l}\text { From this workshop, it was recommended the } \\
\text { inclusion of evaluation and monitoring } \\
\text { components in the management of conservation } \\
\text { areas (Cracco, 2006). }\end{array}$ \\
\hline $\begin{array}{l}1992 \text { Guadalajar } \\
\text { México }\end{array}$ & $\begin{array}{l}\text { "Ibero-American } \\
\text { Congress } \\
\text { Environmental } \\
\text { Education" } \\
\end{array}$ & $\begin{array}{l}\text { Programs were implemented to train } \\
\text { environmental specialists and the organization } \\
\text { and communication between environmental } \\
\text { educators was promoted (Ruvalcaba, 2010). }\end{array}$ \\
\hline $\begin{array}{l}1992 \quad \mathrm{Ca} \\
\text { Venezuela }\end{array}$ & $\begin{array}{l}\text { "Tourism in } \\
\text { Protected Areas" and }\end{array}$ & $\begin{array}{l}\text { It was recognized that tourism contributes to the } \\
\text { conservation and development of local }\end{array}$ \\
\hline
\end{tabular}

uniqueness that best characterize said site or region and the fundamental reason why Eco tourists will want to visit it. Some protected areas exist due to a very special or determined resource that they possess and therefore, also constitutes their main focal attraction.

2. Complementary Attractions: They also refer to elements of natural and / or cultural heritage that are located in a certain area, but do not have the degree of importance or uniqueness in terms of the tourist attraction of the focal attractions. That is, by themselves alone they may not exercise enough attraction to motivate an ecotourist or move to that site. However, they are motivated 
by additional interest and added value for the ecotourist, contributing to a tourist experience of greater wealth and diversity, by indicating the visitor to stay longer in the area in question and to offer the possibility of additional activities. The complementary ecotourism attractions can also help to avoid excessive concentrations of tourists in one place and, at the same time, favor the displacement of visitors to various sites in the corresponding area.

3. Supportive Attractions: These are constituted by the artificial elements already in facilities or services, which provide the visitor with different satisfactions. This includes accommodation, restaurants, interpretation center, trails and viewpoints, horseback riding or boat services, etcetera. The support attractions are always added afterwards, to support the focal and complementary attractions that already exist, by their own nature, in a given ecotourism destination (Lascuráin, 1998).

4. For the average tourist, mere contemplation in a protected area of huge concentrations of waterfowl, is in itself an attraction of the highest level. Although it does not know the specific name of birds, the enormous concentration of these and the form or the different color of some of them will be enough to cause a deep impression in any visitor with a minimum of sensitivity. However, true Eco tourists, both national and foreign, will want to know more about the regions they visit: the structure of their ecosystems, their geological origin and evolution, the main ecological interrelationships that occur there, the regional cultural elements, their environment geographic and the names of the most characteristic or striking plants and animals that are found there, that is, of the focal species (Lascuráin, 1998).

One of the first formal studies that were done about the ecotourism situation in Mexico was the text of Ceballos-Lascuráin in 1994 called National Ecotourism Strategy. In it, a complete diagnosis of the state that kept this activity in the Mexican context, the competitive advantages were described and the need to carry out more research about the economic impacts of this activity was indicated. An action plan is also presented which mentions different parties such as the creation of mechanisms for inter-institutional cooperation, the creation of an inventory of ecotourism products, the creation of an inclusive strategic plan, the design of manuals for the management of environmental and cultural impacts, carrying capacity, training, promotion and the establishment of self-financing mechanisms directed mainly to the conservation of the environment.

Lascurain ends by concluding that ecotourism in Mexico was in its first steps and that following an action plan would ensure a well-organized and oriented development (Guerrero, 2010). However, Rodriguez in 2010 in his article concludes that ecotourism in Mexico is, just a promise. Undoubtedly ecotourism can become a powerful tool for development at any latitude. However, in the case of Mexico, the evidence suggests that this is still not the case and that the outlook is not very favorable for this situation to reverse. The political agenda of Mexico must contemplate the creation of necessary conditions to counteract the above, so that activities such as ecotourism can grow and develop in a positive manner.

Ecotourism promotes the integration of the tourist with the local community through guided walks in areas of fragile ecosystems; such as rainforests or protected natural areas. In this way, possible environmental damage is monitored and it is possible to avoid or minimize it. Through ecotourism it is also possible to amend environmental damage caused previously (Rebollo, 2012).

\section{The City Marketing}

The image of a city is the synthesis of its identity, which is defined by the sum of permanent attributes that make up its essence and serve to differentiate it from other cities. Therefore, the identity of the city has a double dimension: functional and cultural. The functional dimension is specified in its strategic purpose, understood as its raison d'être, and is expressed through its city model, which is nothing more than its strategy to achieve its main objective in the medium and long term, starting from of the set of functional and formal policies. The corporate culture, another dimension of the 
image of identity, is composed of the values shared by all citizens and their presumptions about their city, the environment and everything that may influence it (Betancourt, 2008).

The projection of the image of a city is based on an imaginary, which considers architectural landmarks as "tangible" referents for its inhabitants as well as for visitors, in addition to multiple cultural factors that contribute to forming an "intangible", which significantly affects the perception and choice of products, services and tourist destinations. According to the vision of Mea Della, this is built through a complex process of influences, in which multiple factors of different order intervene:

1. The Natural: Climate, geographical attractions, soil.

2. The Economic: Level of development, activities, products and local brands, services, corporations, technology.

3. The Politicians: System of government, institutional development.

4. The Geopolitical: Historical link with cities, departments.

5. Sociocultural: Population, educational level, cultural expressions, quality of life (Mancilla, Morales \& Lugo, 2012).

City marketing is focused on three basic aspects:

1. For Investors: It is the one that seeks to attract investors and foreign companies, for the creation and / or expansion of new businesses, with the intention of bringing development at the economic level and that is reflected in the increase of capital and sources of employment.

2. For Residents: This is what seeks to attract new residents to the cities, seeking to increase their productive population through attractive programs to obtain permanent resident visas.

3. For Visitors: It is the one that seeks to attract temporary visitors, to encourage tourism and at the same time attract important capital that encourages different tourist sectors.

Specifically, city marketing performs four basic functions:

1. Achieve an optimal combination of the characteristics and services of the city, from the point of view of residents, visitors and investors

2. Articulate an offer of incentives that increases the attractiveness of the city for current and future users of its services

3. Ensure a fast and efficient access of the city to the markets of interest

4. Transmit the image and comparative advantages of the city to the target public.

Undoubtedly, brand management has become one of the mandatory issues for governments and private and public organizations in cities and countries. As are the natural: climate, geographical attractions, soil; the economic: level of development, activities, products and local brands, services, corporations, technology; the politicians: system of government, institutional development; the geopolitical: historical link with cities, departments; the sociocultural: population, educational level, cultural expressions, quality of life. Once again, the management front becomes very important, because thanks to its planning, important achievements can be seen in the strengthening of competitiveness and the image of cities and countries (Martínez, 2007).

Daniel Ivoskus tells that the brand is not a product and this affirmation must be maintained when creating a city brand, which will be recognized in a certain territory. Many authors have tried to classify the city, either by population, geography, maturity, qualitative criteria such as specialization, safety, financial flow, and so on. Marín (2010) and Pablo Lezama give some examples of the city brand as the work on the Barcelona brand, the famous I love NY, Milan or the Armani city, the Argentine Patagonia, Los Angeles and Hollywood; and in addition to places, neighborhoods such as: Tribeca 
and Harlem in New York; Palermo Soho, Barracas Dulce and San Telmo Gay in Buenos Aires. All these are some of the examples of the positioning that was chosen to be constructed to differentiate itself from other places in the world (Marín, 2010).

\section{The Guadalajara Brand}

The government of Zapopan made a presentation of the Guadalajara brand where the former City Major if Guadalajara Enrique Alfaro mentions that the city brand is a reference to avoid the loss of his identity, likewise commented that the brand cares is an element of identity, it is a promotional and positioning tool of Guadalajara that for many years the city needed, that the private sector had requested and that now exists thanks to the will to build a policy of agreements (Government of Zapopan, 2016). In the presentation of the brand, the Governor of the state of Jalisco, Aristóteles Sandoval, also participated. He mentioned that The names of the cities are trademarks, they are reference on an identity.

They have become strategic assets. Having a strong city brand serves to identify, cohesion, and reuse citizenship. It serves to project internationally, attracting projects and investors. "It should be noted that Pablo Lemus also made some comments which are we are one voice, today we show that our identity is to be a Guadalajara. It is a pride to belong to this city, a brand that will have great benefits for all. This is a historical fact that gives voice to \#GuadalajaraGuadalajara congratulations to all that today its brand is presented, our brand" (Valenzuela, 2016).

The city of Guadalajara is the second most populated city in Mexico, after Mexico City, with this exercise of identity it is intended to promote and position the metropolis internationally, increase the tourist influx and continue attracting investments from abroad (García, 2016). The creators of the Guadalajara Guadalajara brand, mention that they took advantage of the great opportunity to build the first sound mark in the world, since the brand is based on the song composed by Pepe Guízar, which represents a natural symbol of the city that reinforces and provokes sensations, emotions and ideas already positioned. The song has the characteristic rhythms of the mariachi and its lyrics take up essential elements of the identity of the city and the region, condensing them into a single phrase: Guadalajara Guadalajara, which is read singing, since it is already positioned at the international level (Valenzuela, 2016).

A very expressive logo has been created, with typographies that vary in size and that remind of the codes used in comics, where try to capture the musicality of this famous chorus in the logo, as mentioned earlier. The typography is the Chinese Rocks Regular, which is used to give a rustic touch that aims to add value to the heritage of a pre-industrial past, where shops or even posters displayed a more standardized and manual design. The brand also has three main and alternating colors: magenta, orange and cyan, which emphasize the colorful character of Mexican folklore (García, 2016).

A reinterpretation of the song was carried out, in which mariachi was mixed with traditional music, elements of rock, electronic and jazz, also collaborated artists such as Venado Azul, a wixarika group of regional music; Telefunka, an electro-acoustic music group; Cuca representing heavy, disruptive rock; Paco Padilla or the Mariachi Viva Xalisco representing the traditional of Mexican music, with; Sara Valenzuela and Abigail Vázquez, outstanding exponents of jazz; Mike Laure Jr. with popular music; in addition, Cecilia Toussaint, Celso Piña, Alfonso André, "the Vampire", Pato Machete, Dr. Shenka with the purpose of integrating all of Mexico (Valenzuela, 2016)

In the competitiveness agendas of tourist destinations in Mexico, it is mentioned that Mexico has not been able to take advantage of the total benefits offered by tourism. A clear example of this is the city of Guadalajara, which is one of the most emblematic states of Mexico. This city is highlighted by its great cultural contribution, tradition and historic buildings, however, has not known how to take advantage of the natural heritage that has to recreational use or tourism, since it has great potential in this sector. There it is entered one of the attractions which is the Santiago river canyon (SECTUR, 2014). 


\section{THE CANYON OF THE SANTIAGO RIVER}

The Santiago river canyon is a natural element of great value, given its level of landscaping, since it has a variety of resources with tourism potential that have not been conveniently used for recreational and tourist use. In addition to the landscape, the canyon contains an important number and variety of resources with tourist potential that until now have not been conveniently used for recreational and tourist use (SECTUR, 2014). This canyon is a resource of such importance that legal instruments have been created for its protection and conservation. The municipality of Guadalajara decreed the area as an Area Subject to Ecological Conservation, while the municipality of Zapopan granted it the category of Municipal Area of Hydrological Protection.

At the federal level, there is a proposal to decree the Barranca del Río Santiago, along the Barranca del Río Verde, as a Protected Natural Area (ANP), without formalizing its legal implementation until now (SECTUR, 2014). However, it is necessary to highlight the environmental problems present in the ravine, since it is one of the most polluted rivers in Mexico due to domestic and industrial discharges, which are mostly not treated. This situation reduces the potential of the Santiago River, which, in its natural context, could well be used for recreational purposes. Despite the condition of the river, the canyon still has a high potential for tourism and recreational use, but public policies aimed at comprehensive sanitation of the Santiago River basin need to be implemented, as well as the implementation of productive and tourist projects that detonate the local development of the area (SECTUR, 2014).

A geographical fact of great magnitude is the one made by the Santiago River over what is now the Barranca that bears his name, giving rise to a depression that in its most eroded part can reach 500 meters of depth, according to the INEGI in the 2010 (SECTUR, 2014). This geological outcrop houses a gallery forest that contains various species of fauna, but especially flora, some of them are even listed as endemic, a situation that makes the Santiago River Canyon even more attractive to be studied and conserved. The problem of this geographical element is the contamination of the Santiago River, which carries all domestic and industrial waste from the Lerma-Chapala-Santiago Basin; however, its main problem is the lack of recognition and appreciation by local inhabitants (SECTUR, 2014). The Barraca del Río Santiago is a natural scenario with great potential for tourism.

In the decade of the 70's a tourist complex was projected for the Barranca del Río Santiago, corresponding to the municipality of Zapopan, where the installation of one or more cable cars, botanical garden, restaurant, bungalows, etc., was contemplated. facilities of Mirador Park Dr. Atl. However, it was only in proposal. In 2005, Guadalajara won the headquarters to house the Guggenheim Museum, which would be located in the grounds surrounding the Mirador Independencia Park in the Santiago River Canyon. In 2009 the project was canceled due to lack of budget. In December 2009 the project "Barranca Museo de Arte Moderno" was announced, which came to replace the Guggenheim.

The project has an approximate cost of 30 million dollars and for 2013 it has an advance of $80 \%$ in its structure. Currently it is planned to make a cable car possible even with Mexican technology, such as Personalized Elevated Urban Transportation (TUEP), proposed in Mexico City, with the support of the Dina Consortium. It is also proposed to rescue the existing infrastructure to install a funicular that goes from Huentitán to the bottom of the Barranca, in the town called Las Juntas in the municipality of Guadalajara and a cost of 320 million pesos is contemplated, which would be invested in an approximately three years (SECTUR, 2014).

According to Martínez in 1984, the Barranca is an impressive broken wall of section in section, by the gaps that in its North slope have opened the rivers that contribute their waters to the Santiago. The panorama that is seen in front of Huentitán, La Experiencia, San Cristóbal, is that of a rock curtain whose almost horizontal folds composed fire and water millions of years ago. The Santiago, "tireless sapper of the Barranca", looks ostentatious to the amazement of passers-by and tourists, analysis and study of geologists and headache of bridge builders, railroads, winches and roads (SECTUR, 2014). 
The potential resources in which they can do better and create recreational activities are presented in Table 3.

There are sites for an adventure in Zapopan as it is the Huaxtla.org site official site of Adventure in Zapopan. This is a non-profit page that seeks to give visitors information about the wonderful routes in contact with nature that Jalisco has and in particular the municipality of Zapopan, to know the Huaxtla Canyon, the Spring Forest, El Cerro del Diente or any other Adventure within the municipality of Zapopan. (Huaxtla, s.f.).

\section{METHODOLOGY}

The methodology of the investigation is made up of a quantitative approach, since for the resolution of contributions, statistical data from a database provided by the government of the state of Jalisco with the intention of giving annual results for the year 2016 were taken into account. The indicators to be rescued were the following: first the motivation to the tourist destinations, means by which they found out, what they liked the most, opinion about the service, as they consider the natural attraction, means by which they arrive to the destination and average cost. This in order to determine if national or domestic tourism is interested in tourism and ecotourism factors.

\section{Type of Study}

The type of research is exploratory. Exploratory studies are usually carried out when the objective is to examine a research topic or problem little studied or that has not been addressed before. That is, when the review of the literature revealed that there are only uninvestigated guidelines and ideas vaguely related to the study problem. Exploratory studies help to increase the degree of familiarity with relatively unknown phenomena. In the case of research was found that there is little, almost nonexistent information about the Santiago river canyon.

The research also uses the descriptive type. A descriptive study selects a series of questions and each of them is measured independently, in order to describe what is being investigated, along the investigation described tourist attractions, ecotourism and city marketing. It should be noted that it is a documentary dissertation, since everything was based on information and there is no sample, no population, no surveys.

\section{Data Analysis}

Based on a study conducted by the government of the State of Jalisco, the following indicators were taken:

1. The means of information by which they learn of a destination $53.1 \%$ by recommendation, $17.2 \%$ Internet, 12.5 by which already knew the place, $5.8 \%$ travel agency, $3 \%$ by mass media and $8.5 \%$ by other means.

2. What they liked most were $28.8 \%$ tourist attractions, $25 \%$ hospitality, $13.12 \%$ destination, $8 \%$ recreational activities, $6.3 \%$ commerce, $5 \%$ tourist services, $4.1 \%$ gastronomy, $3.1 \%$ climate, $2.5 \%$ temples.

3. The opinion on the service is: personal treatment $89.9 \%$ said excellent and $10.1 \%$ said that regular, the price quality ratio, $78 \%$ said excellent, $17 \%$ said regular and 5\% said bad: cleanliness $88.3 \%$ said excellent, $10.4 \%$ said regular and $1.2 \%$ said bad.

4. Different aspects as natural attractive $88.1 \%$ said excellent, $8.9 \%$ said regular and $3 \%$ said bad; Leisure activities $90.1 \%$ said excellent, 9.7 said regular and $.2 \%$ said bad. The means of transport used to reach the destination is $46.1 \%$ automobile, $53.1 \%$ bus. 
Table 3. Resources with tourism potential in the Santiago river Canyon (ZMG)

\begin{tabular}{|c|c|c|c|}
\hline Resources & Sites & Location & Observations \\
\hline Waterfalls & $\begin{array}{l}\text { Las siete } \\
\text { cascadas } \\
\text { Cola de caballo } \\
\text { La soledad } \\
\text { San Lorenzo } \\
\end{array}$ & $\begin{array}{l}\text { Tonalá } \\
\text { Zapopan } \\
\text { Zapopan } \\
\text { Zapopan }\end{array}$ & $\begin{array}{l}\text { Only in rainy season } \\
\text { Inside Parque Mirador Dr. Atl } \\
\text { On the channel of the stream La Soledad } \\
\text { On the channel of the stream Milpillas }\end{array}$ \\
\hline Viewpoints & $\begin{array}{l}\text { Huentitán } \\
\text { Parque mirador } \\
\text { independencia } \\
\text { Dr. Atl } \\
\text { Parque Dr. Atl }\end{array}$ & $\begin{array}{l}\text { Guadalajara } \\
\text { Guadalajara } \\
\text { Guadalajara }\end{array}$ & $\begin{array}{l}\text { Canyon of Huentitán } \\
\text { In this place it is building the Modern } \\
\text { and Contemporary Art Museum of } \\
\text { Guadalajara (Canyon museum) } \\
\text { It is quite deteriorated without attention } \\
\text { of Municipal Government }\end{array}$ \\
\hline Water bodies & 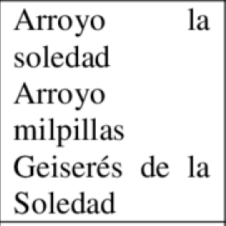 & $\begin{array}{l}\text { Zapopan } \\
\text { Zapopan } \\
\text { Zapopan }\end{array}$ & $\begin{array}{l}\text { Located on the channel of Arroyo la } \\
\text { Soledad }\end{array}$ \\
\hline Canyon & $\begin{array}{l}\text { Cañón Azul } \\
\text { Turqueza } \\
\text { Cañón del Río } \\
\text { Santiago }\end{array}$ & $\begin{array}{l}\text { Guadalajara } \\
\text { Tonalá, } \\
\text { Guadalajara } \\
\text { and Zapopan }\end{array}$ & $\begin{array}{l}\text { It is the canyon formed by the stream La } \\
\text { Soledad } \\
\text { Geographical accident of high landscape } \\
\text { and environmental value for the GMZ }\end{array}$ \\
\hline Elevations & $\begin{array}{l}\text { Peñón de Los } \\
\text { Camachos }\end{array}$ & Zapopan & $\begin{array}{l}\text { From there it is possible to observe a } \\
\text { panoramic view of the Barranca }\end{array}$ \\
\hline Caverns & $\begin{array}{l}\text { Grutas de los } \\
\text { Camachos }\end{array}$ & Zapopan & \\
\hline Spas & $\begin{array}{l}\text { Los Camachos } \\
\text { San José } \\
\text { Huaxtla } \\
\end{array}$ & $\begin{array}{l}\text { Zapopan } \\
\text { Zapopan } \\
\text { Zapopan } \\
\end{array}$ & $\begin{array}{l}\text { First spa of Guadalajara } \\
\text { Community business }\end{array}$ \\
\hline $\begin{array}{l}\text { Routes (Hike, } \\
\text { trekking, } \\
\text { hiking) }\end{array}$ & $\begin{array}{l}\text { Huentitán } \\
\text { Oblatos } \\
\text { Ixtacán-La } \\
\text { Soledad- } \\
\text { Huaxtla } \\
\end{array}$ & $\begin{array}{l}\text { Guadalajara } \\
\text { Guadalajara } \\
\text { Zapopan } \\
\text { Zapopan } \\
\end{array}$ & $\begin{array}{l}\text { Canyon of Huentitán } \\
\text { Canyon of Oblatos } \\
\text { Also as a bicycle route }\end{array}$ \\
\hline $\begin{array}{l}\text { Cultural and } \\
\text { historical } \\
\text { manifestations }\end{array}$ & $\begin{array}{ll}\text { Puente de } \\
\text { Arcediano } \\
\text { Fiesta de los } \\
\text { Tastoanes } \\
\text { Templo de } \\
\text { Ixcatán } \\
\text { Templo de San } \\
\text { esteban } \\
\end{array}$ & $\begin{array}{l}\text { Guadalajara } \\
\text { Zapopan } \\
\text { Zapopan } \\
\text { Zapopan }\end{array}$ & $\begin{array}{l}\text { First suspension bridge in Mexico } \\
\text { In the locality of ixtacán } \\
\text { Franciscan construction dating from } \\
1580 \text {. } \\
\text { Franciscan construction which starts in } \\
1691 \text { and ended in } 1726 \text {. }\end{array}$ \\
\hline
\end{tabular}

\section{CONCLUSION}

As conclusion of the investigation, it is mentioned that the Guadalajara Guadalajara brand only has a cultural and historical focus, leaving behind the ecotourism aspect, which according to the tourism secretary there is a great potential. As it has been mentioned in the competitiveness agendas it has been known to make the most of the Santiago River Canyon. On a national level, the city of Guadalajara is positioned, thanks to the fact that it is based on a very famous song by the composer 
Pepe Guízar, most Mexicans have ever heard it. So broadening an approach of not only seeing the city in an architectural, cultural and religious way, it can be extended to other sectors.

From a national tourism and ecotourism perspective, the answer to our research problem is whether the brand can be extended to this sector with the intention of being able to generate more tourism towards these types of places, along with an extension of work for the hotel industry, to carry out recreational activities that comply with the regulations of the corresponding institutions so as not to cause the already deteriorated ecosystem, but on the contrary to obtain support to be able to clean the area and have one more resource.

However, there have been certain limitations for any improvement project to be presented since the majority must be presented to the secretary of tourism and the next elections in the country each time the strategies are changed depending on the new projects of each governor. This causes that the long-term plans are not feasible. Similarly, it is in conflict since the Guadalajara brand is in the public sector, there is still no support from the private sector, which is why it is more complicated.

\section{PROPOSALS}

1. As a first proposal is the realization of a map that indicates the access and the route to reach the different destinations of the Barranca, since, due to the ignorance of many of the potential tourist attractions, access to these places is difficult, they are not marked, and do not have a structured route.

2. The second proposal is the creation of different zip lines that are attractive to different audiences and ages of visitors. As it can be that of Huentitán to the Boards.

3. Third proposal, that there be a control of contamination, that is, the treatment of wastewater from operation, a good management of solid and liquid waste, the planting and care of the environment or of natural resources, in order to increase the tourist attraction of the place.

4. Fourth proposal to provide support to travel agencies for the preparation of advertising, where they are encouraged to make short trips to the different attractions of the Barranca del Río Santiago. In order to take advantage of the place and boost employment in the tourism sector, the training of employees in order to provide a quality service and experience for people living near the GMZ.

\section{RECOMMENDATION AND LIMITATIONS}

The existing limitations are that there is not much information about the activities that can be carried out in the Santiago River Canyon, in the same way it is important to mention that some areas are not in suitable conditions, because they are contaminated or deteriorated. For this reason, it is recommended that a certain amount of money be invested for the restoration of these areas in order to gradually enable it, so that it can be a potential tourist attraction for the inhabitants of the metropolitan area of Guadalajara, and equally to generate more jobs. In the same way, more research topics can be added to cover issues of restructuring of natural developments, business plans for the ecotourism sector, etc. 


\section{REFERENCES}

Anónimo. (n.d.). 10 problemas que enfrenta el turismo en diferentes ciudades de México. Entorno Turístico. Retrieved from http://www.entornoturistico.com/10-problemas-que-enfrenta-el-turismo-en-diferentes-ciudadesde-mexico/

Aldaz, P. (2016). La CDMX ya es una marca registrada. El universal. Retrieved from http://www.eluniversal. com.mx/articulo/metropoli/df/2016/01/27/la-cdmx-ya-es-una-marca-registrada

Aragón, M. (2014). Análisis del ecoturismo como alternativa de desarrollo sustentable en Latinoamérica. El Colegio de la Frontera Sur, Université de Sherbrooke.

Armas, A. (2007). En torno a la mercadotecnia urbana: reorganización y reimaginación de la ciudad. Revista bibliográfica de geografía y ciencias sociales. Retrieved from http://www.ub.edu/geocrit/b3w-712.htm

Aventura en Zapopan. (n.d.). Viajes Huaxtla. Retrieved from http://www.huaxtla.org/index.php

Báez, L., \& Acuña, A. (1998). Guía para las mejores prácticas de ecoturismo en las Áreas Protegidas de Centro América. Turismo \& Conservación Consultores, S.A. Retrieved from http://www.bio-nica.info/biblioteca/ Baez\&Acuna\%201998.pdf

Benko, G. (2000). Estrategias de comunicación y marketing urbano. SciELO. Retrieved from https://scielo. conicyt.cl/scielo.php?script=sci_arttext\&pid=S0250-71612000007900004

Betancourt, Y. E. (2008). El city marketing como una opcion estrategica de mercados. Universidad Nacional de Colombia. Retrieved from http://www.bdigital.unal.edu.co/1949/1/yesideduardobetancourt.2008.pdf

Bielsa, M. (2016). City Branding, el marketing de la cuidad. Mique. Retrieved from http://www.mique.es/citybranding-el-marketing-de-la-ciudad/

Catellanos, C. (2015). Evaluación de los recursos turísticos con vocación ecoturistica y caracterización de la demanda turística en las zonas de uso público de la reserva forestal protectora del cerro quininí (Tibacuycundinamarca). Colciencias. Retrieved from http://repository.udistrital.edu.co/bitstream/11349/2383/1/ CastellanosMenjuraClaudiaPatricia2015.pdf

Consultoria Mitosky. (2016). LOS ORGULLOS DE LOS MEXICANOS. Mexico opina. Retrieved from http:// consulta.mx/index.php/estudios-e-investigaciones/mexico-opina/item/821-los-orgullos-de-los-mexicanos

Comunicación social, eventos, gobierno noticias (2016). Presentan "Guadalajara Guadalajara", la nueva marca cuidad. Gobierno de zapopan. Retrieved from https://www.zapopan.gob.mx/presentan-guadalajara-guadalajarala-nueva-marca-ciudad/

CPTM. (2014). Programa Institucional 2014-2017. Consejo de Promoción Turística de México. Retrieved from http://www.cptm.com.mx/work/models/CPTM/Resource/8183/8/images/Anexo_13_Programa_ Institucional_2014_2018_CPTM.pdf

CPTM. (2017). Internet. Consejo de Promoción Turística de México. Retrieved from http://www.cptm.com. $\mathrm{mx} /$ services/internet

García, M. (2016). La ciudad mexicana de Guadalajara presenta su nueva marca, basada en la famosa canción. Brandemia. Retrieved from http://www.brandemia.org/la-ciudad-mexicana-de-guadalajara-presenta-su-nuevamarca-basada-en-la-famosa-cancion

Guadalajara Guadalajara. (2016). Retrieved from https://guadalajaraguadalajara.mx/

Guerrero, R. (2010), Ecoturismo Mexicano: la promesa, la realidad y el futuro. Un análisis situacional mediante estudios de caso. Redalyc. Retrieved from http://www.redalyc.org/articulo.oa?id=193414423002

Heredero, O., \& Chaves, M. (2015). Las asociaciones "marca producto" y "marca ciudad" como estrategia de "city branding:" Una aproximación a los casos de Nueva York, París y Londres. Universidad Complutense de Madrid. Retrieved from http://revistas.ucm.es/index.php/ARAB/article/view/47857

Hernández, E. (2014). El city marketing como estrategia de mercados para el desarrollo turistico, caso de estudio Ixtapa de la sal [Tesis]. Universidad Autonoma de Mexico. Retrieved from http://ri.uaemex.mx/bitstream/ handle/20.500.11799/30993/UAEM-FAPUR-TESIS-HERNANDEZ,\%20ESTEBAN.pdf?sequence= 
Lascuráin, H. (1998). Elaboración de Inventarios de Atractivos Ecoturísticos. Diana. Retrieved from http://www. ucipfg.com/Repositorio/MGTS/MGTS14/MGTSV-07/tema2/Ceballos-Lascurain.pdf

Lloyd, C., Quercus, M., \& Medina, L. (n.d.). Cañon 7 cascadas. Jalisco Vertical. Retrieved from http:// jaliscovertical.weebly.com/7-cascadas.html

Mancilla, E., Morales, A., \& Lugo, D. (2012). El papel imaginario urbano para la construcción de la marca de una cuidad. Imaginario Visual. Retrieved from http://eprints.uanl.mx/2551/1/El_papel_del_imaginario.pdf

Marín, N. C. (2010). Promoción turística a través de los medios audiovisuales, Caso Medellín, Colombia. Universidad Internacional de Andalucía. Retrieved from dspace.unia.es/bitstream/handle/10334/757/0139_ Gomez.pdf?sequence $=3$

Martínez, A. (2006). Creación de una marca de cuidad. Instituto Nacional de Administración Pública Centro de Estudios Locales. Retrieved from http://bases.cortesaragon.es/bases/ndocumen.nsf/9ed3a8f9c37405f6c125 70a6002b471d/24c0c410f75ea060c12575d8002abad1/\$FILE/creacin\%20marca\%20de\%20una\%20ciudad.pdf

Melo, J. (2013). El ecoturismo como desarrollo sustentable. UNAM. Retrieved from http://132.248.9.195/ ptd2014/enero/0707347/0707347.pdf

Navarro, D. (2015). Recursos turísticos y atractivos turísticos: Conceptualización, clasificación y valoración. Cuadernos del turismo. Retrieved from http://www.redalyc.org/pdf/398/39838701014.pdf

OMT. (2008). Entender el turismo: Glosario Básico. UNWTO. Retrieved from http://media.unwto.org/es/content/ entender-el-turismo-glosario-basico\#Turismo\%20interno

Portugal, M. (2008). Introducción al turismo. Transversal. Retrieved from http://enah.edu.ni/files/uploads/ biblioteca/902.pdf

Rebollo, N. (2012). Ecoturismo. Red Tercer Milenio. Retrieved from http://www.aliat.org.mx/BibliotecasDigitales/ economico_administrativo/Ecoturismo.pdf

Rogel, I., Rojas, A., \& Ortega, S. (2011). El turismo alternativo como estrategia de conservación de la reserva de la biosfera de la Mariposa Monarca (2008-2010). Quivera. Retrieved from http://www.redalyc.org/ pdf/401/40119956006.pdf

Rojano, F. J., \& Castilla, E. B. (2007). Presente y futuro de la comunicación estratégica en la ciudad. Fisecestrategias Revista Académica del Foro Iberoamericano sobre Estrategias de Comunicación, 30. Retrieved from http://www.cienciared.com.ar/ra/usr/9/318/fisec8m4_pp27_49.pdf

Romero, E. (2009). City-marketing, Marca-cuidad. Comunicaciones Estratégicas. Retrieved from http:// romeroads.blogspot.mx/2009/04/city-marketing-marca-ciudad.html?view=classic

Sancho, A. (2008). Introducción al turismo. E-unwto.org. Retrieved from http://moodle2.unid.edu.mx/dts_ cursos_mdl/lic/AET/PT/AM/01/Introduccion_turismo.pdf

SECTUR. (2014). Agendas de competitividad de los destinos turísticos de México. Secturjal. Retrieved from https://secturjal.jalisco.gob.mx/sites/secturjal.jalisco.gob.mx/files/u16/agenda_guadalajara.pdf

Valenzuela, R. (2016). Guadalajara, Guadalajara. Una marca sonora. Campaings \& Elections en español. Retrieved from https://www.campaignsandelectionsla.com/single-post/2016/10/01/Guadalajara-GuadalajaraUna-marca-sonora

Wallingre, N. (2011). El desarrollo de un nuevo destino turístico el caso de la ciudad de Villa Elisa. Argentina: Dialnet.

Wallingre, N., \& Toyos, M. (2010). Diccionario de turismo, hotelería y transportes (2nd ed.). Buenos Aires: Universidad del Salvador. 


\section{APPENDIX A: KEY TERMS AND DEFINITIONS}

Barranca del Río Santiago: is a long-standing nature interaction space, has constituted border, edge, meeting place. As of October 2004, it is declared Municipal Area of Hydrological Protection "Barranca del Río Santiago." The area has a total of 17729.91 hectares.

Brand Guadalajara Guadalajara: The brand "Guadalajara, Guadalajara", which is in a stage of positioning in order to know the activities that have been done in terms of promotion and growth of cultural identity and its tourist vocation of the city. The territory is not only a place or a physical space, it is the surface where the natural and social processes are developed, because there interact the agents and interest groups, the people who create political, economic and social relations.

City Brand: A city brand is the name of the city to which a series of unique and exclusive attributes are associated by which it is possible to identify, recognize and differentiate said city from others.

Ecotourism: or ecological tourism is the tourist activity that develops without altering the balance of the environment and avoiding the damage to nature. It is a trend that seeks to make the tourism industry compatible with ecology.

Guadalajara: Guadalajara is the name of the capital of Jalisco. It means 'river of stones', 'river that runs between stones', or 'valley of fortresses'. It comes from the Arabic وادي الحجارة 'wādi al-hiyara), which can be translated as 'valley of stone.'

Place Branding: is the process of promoting images specifically selected in order to establish a favorable reputation that serves as a tourist attraction.

Protected natural area: Protected Natural Area (ANP) is a portion of territory (terrestrial or aquatic) whose purpose is to conserve the representative biodiversity of the ecosystems to ensure the balance and continuity of the evolutionary and ecological processes and whose characteristics have not been essentially modified.

José G. Vargas-Hernández, M.B.A., Ph.D., Member of the National System of Researchers of Mexico and a research professor at University Center for Economic and Managerial Sciences, University of Guadalajara. Professor Vargas-Hernández has a Ph. D. in Public Administration and a Ph.D. in Organizational Economics. He has undertaken studies in Organisational Behaviour and has a Master of Business Administration, published four books and more than 200 papers in international journals and reviews (some translated to English, French, German, Portuguese, Farsi, Chinese, etc.) and more than 300 essays in national journals and reviews. He has obtained several international awards and recognition. 